\title{
Mitochondrial Genome-Knockout Cells Demonstrate a Dual Mechanism of Action for the Electron Transport Complex I Inhibitor Mycothiazole
}

\author{
Kirsten J. Meyer ${ }^{1}$, A. Jonathan Singh ${ }^{2}$, Alanna Cameron ${ }^{3}$, An S. Tan ${ }^{3}$, Dora C. Leahy ${ }^{1}$, \\ David O'Sullivan ${ }^{1}$, Praneta Joshi ${ }^{1}$, Anne C. La Flamme ${ }^{1}$, Peter T. Northcote ${ }^{2}$, \\ Michael V. Berridge ${ }^{3}$ and John H. Miller ${ }^{1, *}$
}

1 Centre for Biodiscovery and Schools of Biological Sciences, Victoria University of Wellington, PO Box 600, Wellington, New Zealand; E-Mails: kirstenjoymeyer@hotmail.com (K.J.M.); dora.leahy@gmail.com (D.C.L.); david.osullivan@vuw.ac.nz (D.O.); praneta.joshi@spcorp.com (P.J.); anne.laflamme@vuw.ac.nz (A.C.L.F.)

2 Centre for Biodiscovery and School of Chemical and Physical Sciences, Victoria University of Wellington, PO Box 600, Wellington, New Zealand; E-Mails: jonathan.singh@vuw.ac.nz (A.J.S.); peter.northcote@vuw.ac.nz (P.T.N.)

3 Malaghan Institute of Medical Research, Wellington, New Zealand; E-Mails: acameron@malaghan.org.nz (A.C.); antan@malaghan.org.nz (A.S.T.); mberridge@malaghan.org.nz (M.V.B.)

* Author to whom correspondence should be addressed; E-Mail: john.h.miller@vuw.ac.nz; Tel.: +64-4-463-6082; Fax: +64-4-463-5331.

Received: 19 March 2012; in revised form: 10 April 2012 / Accepted: 12 April 2012 / Published: 16 April 2012

\begin{abstract}
Mycothiazole, a polyketide metabolite isolated from the marine sponge Cacospongia mycofijiensis, is a potent inhibitor of metabolic activity and mitochondrial electron transport chain complex I in sensitive cells, but other cells are relatively insensitive to the drug. Sensitive cell lines $\left(\mathrm{IC}_{50} 0.36-13.8 \mathrm{nM}\right)$ include HeLa, P815, RAW 264.7, MDCK, HeLa S3, 143B, 4T1, B16, and CD4/CD8 T cells. Insensitive cell lines $\left(\mathrm{IC}_{50}\right.$ 12.2-26.5 $\mu \mathrm{M}$ ) include HL-60, LN18, and Jurkat. Thus, there is a 34,000-fold difference in sensitivity between HeLa and HL-60 cells. Some sensitive cell lines show a biphasic response, suggesting more than one mechanism of action. Mitochondrial genome-knockout $\rho^{0}$ cell lines are insensitive to mycothiazole, supporting a conditional mitochondrial site of action. Mycothiazole is cytostatic rather than cytotoxic in sensitive cells, has a long lag period of about $12 \mathrm{~h}$, and unlike the complex I inhibitor, rotenone,
\end{abstract}


does not cause $\mathrm{G}_{2} / \mathrm{M}$ cell cycle arrest. Mycothiazole decreases, rather than increases the levels of reactive oxygen species after $24 \mathrm{~h}$. It is concluded that the cytostatic inhibitory effects of mycothiazole on mitochondrial electron transport function in sensitive cell lines may depend on a pre-activation step that is absent in insensitive cell lines with intact mitochondria, and that a second lower-affinity cytotoxic target may also be involved in the metabolic and growth inhibition of cells.

Keywords: metabolic inhibitor; mitochondrial electron transport complex I; mycothiazole; natural product; reactive oxygen species

\section{Introduction}

Mycothiazole (MYZ, Figure 1) is a polyketide heterocycle first isolated from the marine sponge Spongia mycofijiensis in 1988 [1] and shown to be anti-helminthic and toxic to mice. Structural analog studies revealed that the thiazole component of MYZ was important for its bioactivity [2]. The original chemical structure of MYZ as proposed by Crews et al. [1] was later found to be incorrect, and a corrected structure was subsequently published in 2006 [3]. Screened against the NCI panel of 60 cancer cell lines, MYZ displayed a broad range of activities in different cell lines with potent nanomolar activity against small (SCLC) and non-small (NSCLC) cell lung cancer cell lines [4].

Figure 1. Structure of mycothiazole.

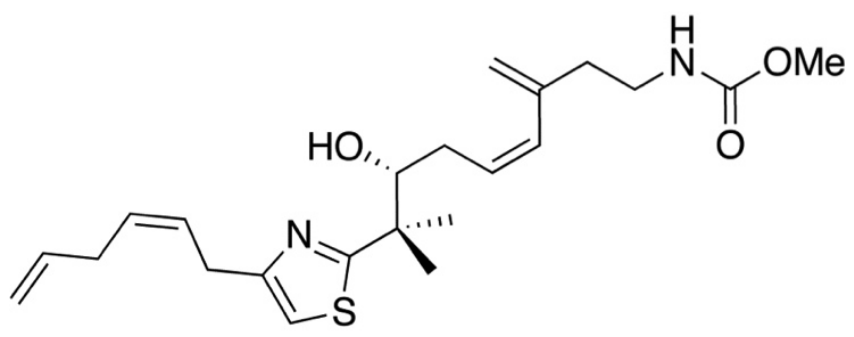

MYZ was shown to inhibit hypoxia-inducible factor-1 (HIF-1) by Nagle and colleagues [5]. Later work by the same group showed MYZ to be an inhibitor of complex I (NADH-ubiquinone oxidoreductase) of the mitochondrial electron transport (MET) chain [6]. Using a digitonin-permeabilized human breast tumor T47D cell line, MYZ was shown to act like rotenone in inhibiting oxygen consumption by the cells following addition of malate/pyruvate. The block by MYZ was completely reversed by addition of succinate, which bypasses complex I and passes electrons directly to complex II. MET chain inhibitors such as rotenone (CI), malonate (CII), antimycin A (CIII), and cyanide (CIV) act by direct inhibition of the protein complexes, or by acting as electron acceptors and disrupting the chain [7]. Reactive oxygen species (ROS) are largely produced at complexes I and III [8], but ROS can also be produced from complex II [9]. Complex I inhibitors, by altering mitochondrial function, are potential cancer chemotherapeutic agents because of the links of mitochondria to apoptosis and their effects on bioenergetics and ROS production [10,11]. Thus, the National Cancer Institute (NCI) carried out a data mining screen for potential novel complex I inhibitors, and of 10 compounds selected for 
possible activity, 5 showed good inhibition of complex I [10]. Complex I inhibitors, like rotenone and the annonaceous acetogenin bullatacin, for example, bind to a $30 \mathrm{kDa}$ protein that is part of the DN1 subunit of complex I [11]. Bullatacin also inhibits the NADH oxidase found in the plasma membrane of tumor cells that allows the cells to produce ATP in the hypoxic environment of the tumor; thus, this complex I inhibitor blocks both oxidative and anaerobic ATP and nucleotide production.

In addition to MET, a trans-plasma membrane electron transport (tPMET) system exists consisting of NADH oxidases and ubiquinone that makes use of extracellular, rather than intracellular, oxygen $[12,13]$. This system has been most clearly demonstrated in cells that lack mitochondrial DNA ( $\rho^{0}$ cells) [14]. These $\rho^{0}$ cells have no functional MET since 13 subunits of the four MET complexes are encoded in the mitochondrial genome [15].

The purpose of the present study was to investigate the action of MYZ in different cancer cell lines and to determine the effect of the drug on cellular bioenergetics using $\rho^{0}$ cells that lack mitochondrial DNA and therefore have no functional complex I. This approach has the potential to unmask a secondary mode of action of MYZ that could explain a biphasic activity seen in some cells and may provide information on its nanomolar mechanism of action in sensitive cells and its micromolar activity in resistant cells.

\section{Results and Discussion}

\subsection{Mycothiazole Isolation and Purification}

Mycothiazole (MYZ) (Figure 1) was isolated and purified from the Tongan marine sponge Cacospongia mycofijiensis as described in the experimental section. Four other compoundslatrunculin A, dendrolasin, laulimalide, and zampanolide-were also isolated from the same sponge species [16].

\subsection{Effects of MYZ on Cell Metabolism and the Proliferative Response}

The concentrations of MYZ that produced 50\% inhibition $\left(\mathrm{IC}_{50}\right)$ of MTT reduction for cell lines or CSFE proliferation for $\mathrm{T}$ cells were determined using eleven established cell lines and primary murine splenic T-cells (Table 1). These cells showed diverse responses to MYZ, with most cell lines (HeLa, P815, HeLaS3, 143B, B16, 4T1, MDCK, and RAW264.7) and the murine T-cells being highly sensitive, and three cell lines (HL-60, LN18 and Jurkat) being relatively resistant to the drug. For example, HL-60 cells had a mean $\mathrm{IC}_{50}$ value of $12 \mu \mathrm{M}$; whereas, HeLa were highly sensitive with a mean $\mathrm{IC}_{50}$ of $0.36 \mathrm{nM}$ (Table 1, Figure 2A,B). In contrast, P815 and MDCK cells exhibited a biphasic response (Table 1, Figure 2C,D); thus, low nanomolar concentrations of MYZ inhibited MTT responses of these cells by about 50\%; whereas, more extensive inhibition was observed at micromolar concentrations, suggesting both high and low-sensitivity mechanisms of action. Preliminary attempts to investigate cell recovery by washing out MYZ for $24 \mathrm{~h}$ after a $24 \mathrm{~h}$ exposure showed that some cell lines (e.g., 143B) remained sensitive after washout, others (P815) were partially reversed in their ability to proliferate, and some, like HeLa, completely recovered from the effects of the drug (data not shown). ${ }^{3} \mathrm{H}$-thymidine uptake was used to confirm that the MTT assay was measuring a proliferative response and not just metabolic depression of non-dividing cells (Figure 3). 
Figure 2. Concentration-dependent effects of Mycothiazole (MYZ) on selected cell lines. Representative graphs of $48 \mathrm{~h}$ 3-(4,5-dimethylthiazol-2-yl)-2,5-diphenoyltetrazolium bromide (MTT) assays with MYZ in HL-60/HL60 $\rho^{0}$ cells (A), HeLa/HeLa ${ }^{0}$ cells (B), P815/P815 $\rho^{0}$ cells $(\mathbf{C})$, and MDCK cells (D). The $\mathrm{IC}_{50}$ values are given at the bottom of each graph ( $n=3$ or more independent experiments).

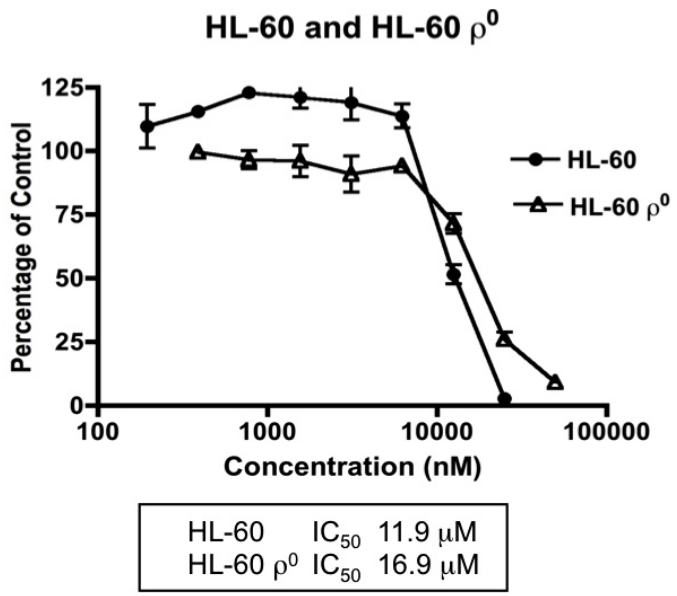

(A)

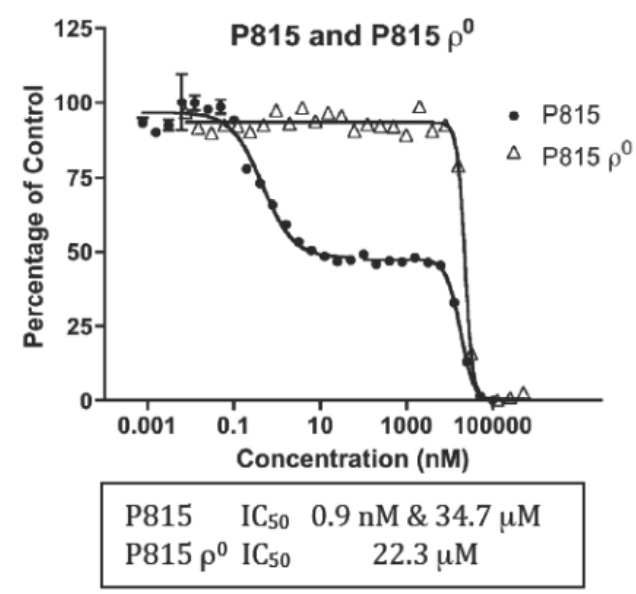

(C)

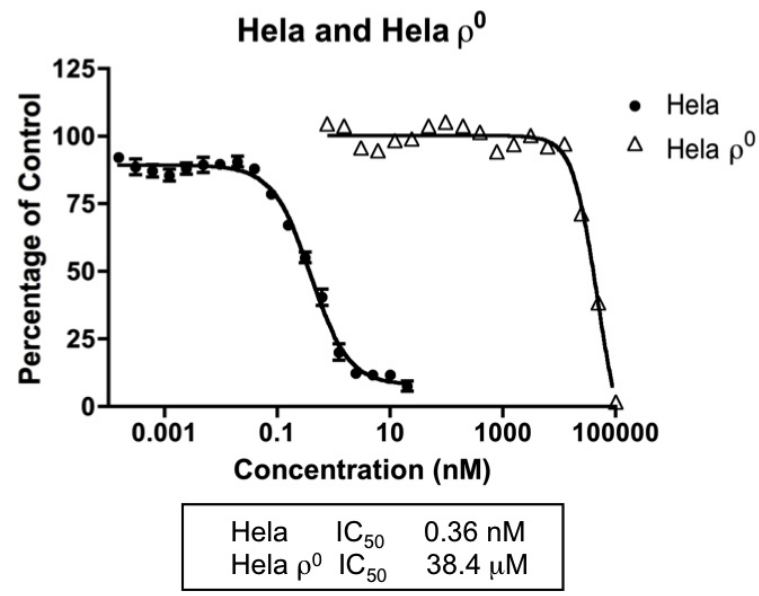

(B)

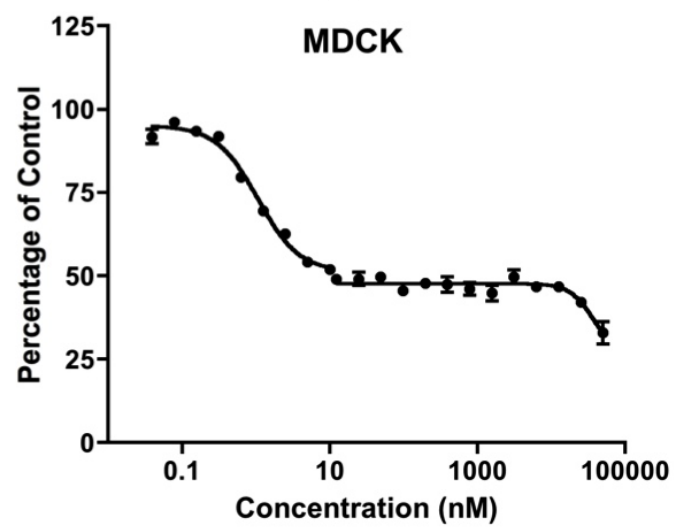

- MDCK IC I0 $_{50} 1.06 \mathrm{nM} \& 91.1 \mu \mathrm{M}$

Table 1. Summary of MYZ effects on cellular MTT and carboxyfluorescein succinimidyl ester (CFSE) responses. $\mathrm{IC}_{50}$ values were determined by MTT reduction at $48 \mathrm{~h}$ in different cell lines and by the CFSE proliferation assay for the T cells. Note the biphasic response of P815 and MDCK cells.

\begin{tabular}{|c|c|c|c|c|c|}
\hline Parental Cell Lines & $\mathrm{IC}_{50}($ Mean \pm SEM $)$ & $n$ & $\rho^{0}$ Cell Lines & $\mathrm{IC}_{50}($ Mean $\pm \mathrm{SEM})$ & $n$ \\
\hline \multicolumn{6}{|l|}{ Sensitive } \\
\hline $\mathrm{HeLa}$ & $0.36 \pm 0.09 \mathrm{nM}$ & 4 & $\operatorname{HeLa}^{0}$ & $78.4 \pm 20.2 \mu \mathrm{M}$ & 3 \\
\hline HeLa S3 & $1.84 \mathrm{nM}$ & 2 & & & \\
\hline 143B & $3.24 \pm 1.6 \mathrm{nM}$ & 4 & $143 \mathrm{~B} \rho^{0}$ & $50.7 \mu \mathrm{M}$ & 1 \\
\hline B16 & $13.8 \pm 3.6 \mathrm{nM}$ & 3 & $\mathrm{~B} 16 \rho^{0}$ & $34.7 \mu \mathrm{M}$ & 1 \\
\hline $4 \mathrm{~T} 1$ & $12.1 \pm 2.5 \mathrm{nM}$ & 3 & & & \\
\hline RAW 264/7 & $1.54 \mathrm{nM}$ & 2 & & & \\
\hline Primary & CD4 $2.04 \pm 0.37 \mathrm{nM}$ & 5 & & & \\
\hline T Cells & CD8 $7.20 \pm 0.52 \mathrm{nM}$ & 5 & & & \\
\hline
\end{tabular}


Table 1. Cont.

\begin{tabular}{clllll}
\hline Biphasic & & & & & \\
\hline P815 & (a) $1.02 \pm 0.22 \mathrm{nM}$ & 4 & P815 $\rho^{0}$ & $36.4 \pm 9.2 \mu \mathrm{M}$ & 3 \\
& (b) $30.3 \pm 5.1 \mu \mathrm{M}$ & 5 & & & \\
MDCK & (a) $1.47 \pm 0.79 \mathrm{nM}$ & 3 & & & \\
& (b) $91.1 \mu \mathrm{M}$ & 1 & & & \\
\hline Insensitive & & & & & \\
\hline HL-60 & $12.2 \pm 2.2 \mu \mathrm{M}$ & 5 & HL-60 $\rho^{0}$ & $26.1 \pm 9.2 \mu \mathrm{M}$ & 2 \\
LN18 & $26.5 \pm 3.1 \mu \mathrm{M}$ & 3 & & & \\
Jurkat & $26.5 \mu \mathrm{M}$ & & & & \\
\hline
\end{tabular}

Figure 3. Effects of MYZ on ${ }^{3} \mathrm{H}$-thymidine uptake by HeLa and P815 cells after $24 \mathrm{~h}$ and $48 \mathrm{~h}$ exposure. Representative graphs are shown from two independent experiments. HeLa (A, B) and P815 (C, D) cells were exposed to $50 \mathrm{nM} \mathrm{MYZ} \mathrm{for} 24 \mathrm{~h} \mathrm{(A,} \mathrm{C)} \mathrm{and} 48 \mathrm{~h}$ (B, D), and ${ }^{3} \mathrm{H}$-thymidine was added during the last $8 \mathrm{~h}$ of culture.

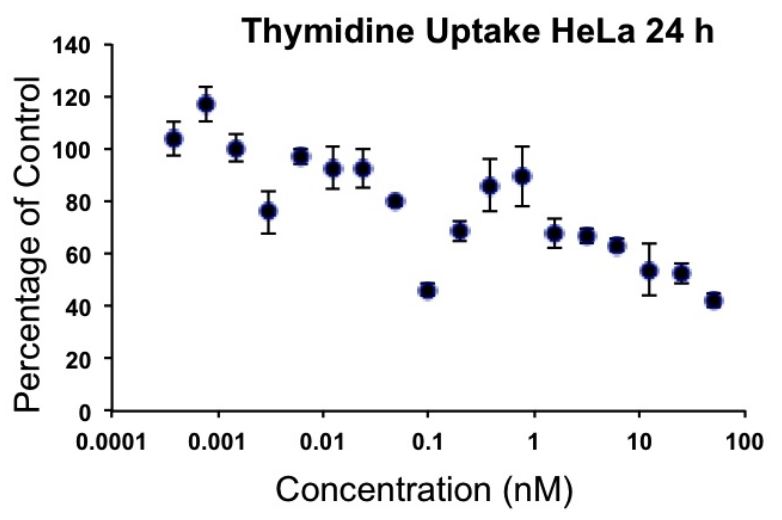

(A)

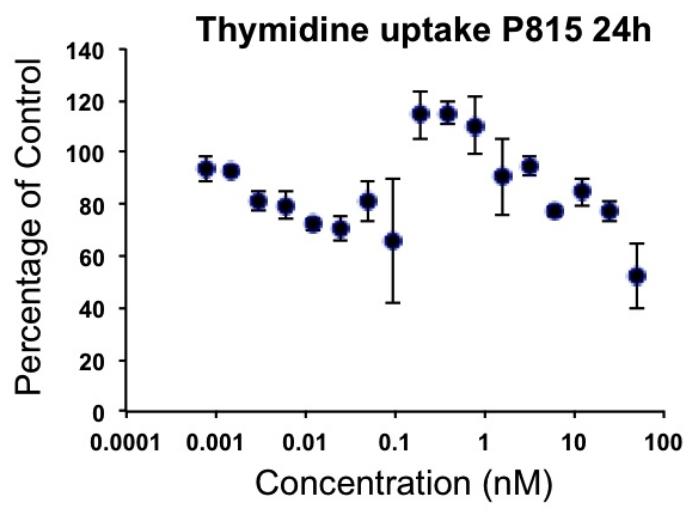

(C)

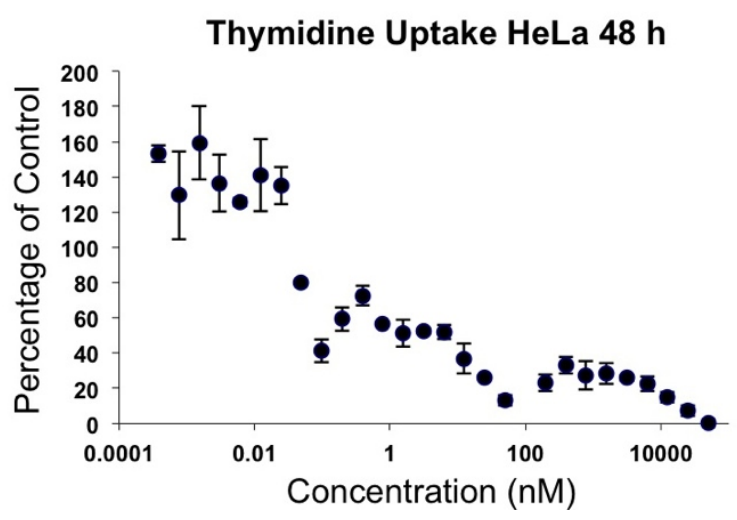

(B)

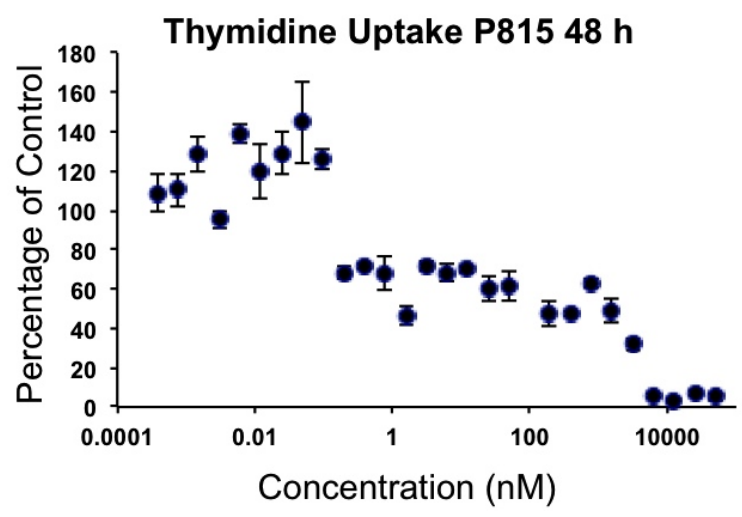

(D)

MYZ has been shown to inhibit complex I of MET, and therefore cell lines lacking MET were used to investigate how this would effect the MYZ potency. Ablation of MET function in HL-60 cells by mitochondrial genome deletion (HL-60 $\rho^{0}$ cells) had little effect on the $\mathrm{IC}_{50}$ value for MYZ (26 $\mu \mathrm{M}$ compared to $12 \mu \mathrm{M}$ in the parental cell line) (Table 1, Figure $2 \mathrm{~A}$ ). On the other hand, the $\mathrm{IC}_{50}$ for MYZ with HeLa $\rho^{0}$ cells (Table 1, Figure 2B) was $78 \mu \mathrm{M}$ compared to $0.36 \mathrm{nM}$ in the parental cell line - a 217,000-fold decrease in sensitivity in the absence of MET function. In all cases, $\rho^{0}$ cells were 
highly insensitive to the action of MYZ with $\mathrm{IC}_{50}$ values in the $26-78 \mu \mathrm{M}$ range. In $\mathrm{P} 815 \rho^{0}$ cells the initial 50\% reduction in MTT response to nanomolar concentrations of MYZ was lost. An $\mathrm{IC}_{50}$ value of $22 \mu \mathrm{M}$ was observed, the MTT reduction occurring in the same concentration range as the micromolar part of the biphasic response in P815 cells $(17 \mu \mathrm{M})$.

\subsection{Effects of MYZ on Cell Viability}

To distinguish cytotoxic from cytostatic effects, trypan blue dye exclusion was used with HeLa, P815, and HL-60 cells (Figure 4). MYZ treatment at concentrations as high as $25 \mu \mathrm{M}$ had little effect on the viability of HeLa and P815 cells, even after $48 \mathrm{~h}$ incubation with the drug. With HeLa cells, $50 \%$ cytotoxicity was seen after $48 \mathrm{~h}$ exposure to $100 \mu \mathrm{M} \mathrm{MYZ} \mathrm{(Figure} \mathrm{4A),} \mathrm{and} \mathrm{with} \mathrm{P815} \mathrm{cells,}$ 25-30 h exposure to $50 \mu \mathrm{M} \mathrm{MYZ}$ resulted in 40\% loss of viable cells (Figure 4B). Thus, the cytotoxic effects of MYZ were only seen at concentrations four or more orders of magnitude above the $\mathrm{IC}_{50}$ concentration determined in the MTT assay. In contrast, treatment of HL-60 cells with MYZ at a concentration comparable to its $\mathrm{IC}_{50}$ in the MTT assay $(25 \mu \mathrm{M})$ resulted in complete loss of viability (Figure 4C). Cytotoxic effects of MYZ with HL-60 cells were evident as early as $5 \mathrm{~h}$ following exposure.

Figure 4. Effects of MYZ on cell viability of HeLa, P815, and HL-60 cells. Cells were exposed to MYZ for various times, and the percent viability was determined by trypan blue dye exclusion. HeLa cells (A) and P815 cells (B) were exposed to MYZ at concentrations ranging from $0-100 \mu \mathrm{M}$. HL-60 cells were treated with vehicle or $25 \mu \mathrm{M} \mathrm{MYZ} \mathrm{(C).}$ Results are representative of 3 or more independent experiments.

Cell viability of HeLa cells treated with MYZ

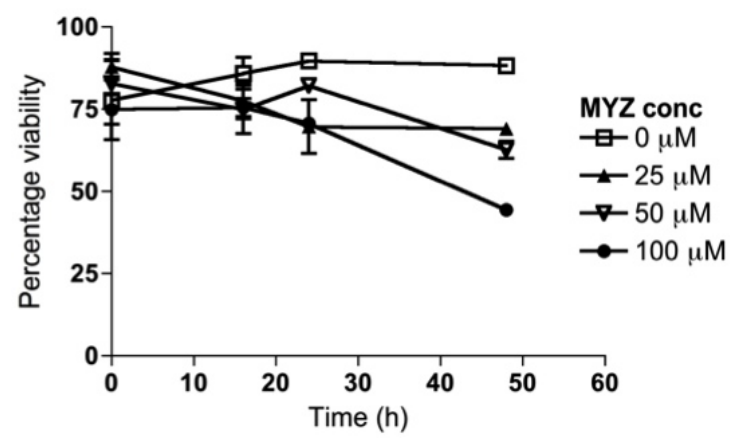

(A)

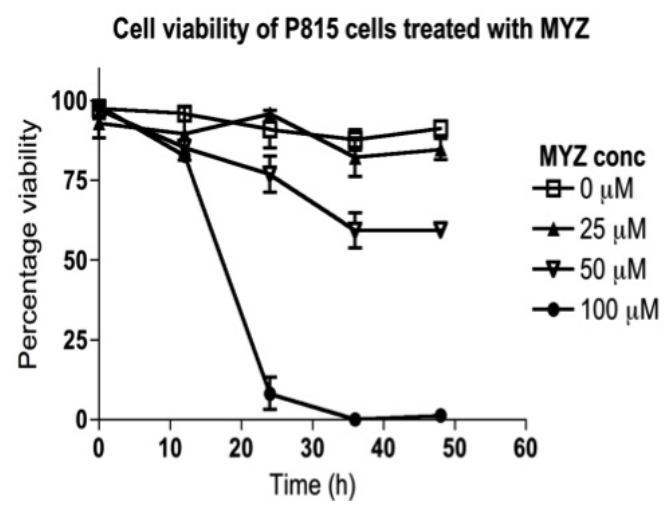

(B)

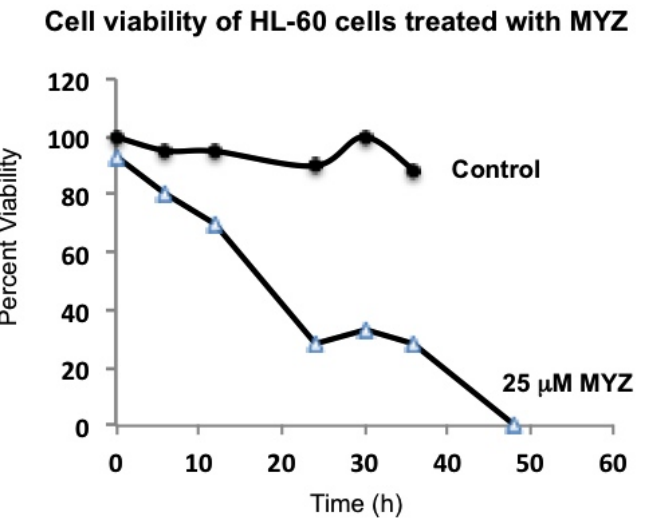

(C) 


\subsection{Lag before MYZ Exerts Its Effects on Cell Metabolism}

To investigate the kinetics of metabolic inhibition by MYZ, MTT assays were performed on P815 cells treated with MYZ for 0, 12, 24, and $48 \mathrm{~h}$ (Figure 5). There was an unexpected lag period of $12 \mathrm{~h}$ before the MTT response began to be affected by MYZ. The threshold concentration required to give an effect on metabolism was about $0.1 \mathrm{nM}$ MYZ. As expected, inhibition at each concentration increased with longer exposure times.

Figure 5. Effect of time of exposure to MYZ on MTT reduction by P815 cells. Representative graphs are presented of MTT assays after different MYZ exposure times of $0 \mathrm{~h}, 12 \mathrm{~h}, 24 \mathrm{~h}$, and $48 \mathrm{~h}$. For the $0 \mathrm{~h}$ treatment, MTT reagents were added immediately after the MYZ was added to the cells. Results are representative of two independent experiments.

$0 \mathrm{hr}$ Myz treatment

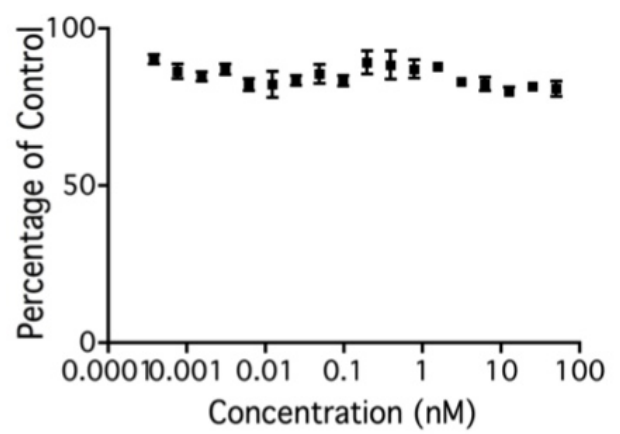

$24 \mathrm{hr}$ Myz treatment

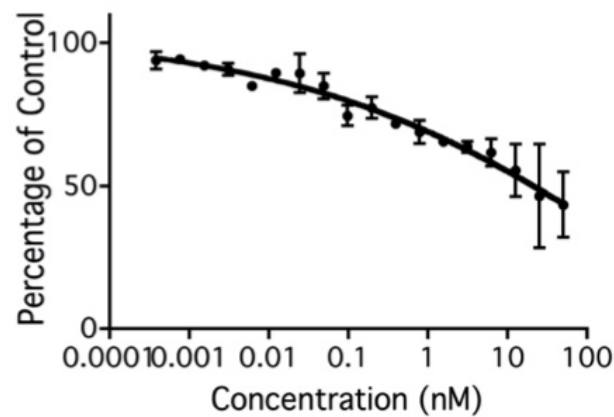

$12 \mathrm{hr}$ Myz treatment

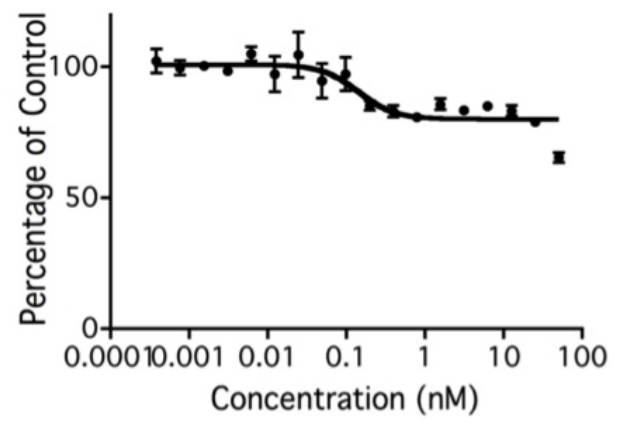

$48 \mathrm{hr}$ Myz treatment

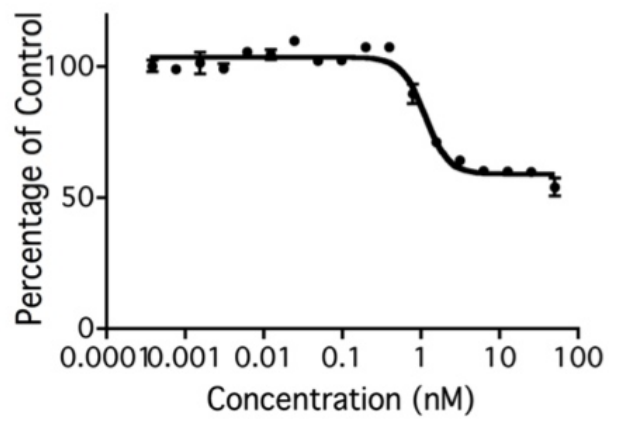

\subsection{Effects of MYZ on the Cell Cycle}

Using flow cytometry of PI-stained cells, the effects of MYZ on progression of HeLa cells through the cell cycle were investigated. MYZ after $16 \mathrm{~h}$ exposure had no effect on cell cycle progression at concentrations up to $100 \mathrm{nM}$, three orders of magnitude greater than the $\mathrm{MTT} \mathrm{IC}_{50}$, (Table 2). Synchrony of HeLa cells with $2 \mathrm{mM}$ thymidine block, then release also showed no significant changes in cell cycle distribution (data not shown). A similar lack of a cell cycle effect was seen with HL-60 cells at concentrations from $0.1-50 \mu \mathrm{M}$ ( $n=3$ preparations) (Figure S2 of Supplementary Data). To ensure a block was not missed in the HeLa cells, concentrations up to $20 \mu \mathrm{M}$ and exposures up to $48 \mathrm{~h}$ were also tested, and again, no treatment resulted in cell cycle arrest (Figure 6). 
Table 2. Lack of MYZ effect on the cell cycle of HeLa cells after $16 \mathrm{~h}$ exposure. HeLa cells were treated with $0,0.1,1,10$, and $100 \mathrm{nM} \mathrm{MYZ}$ for $16 \mathrm{~h}$, and the $\%$ of cells in each phase of the cell cycle was determined ( $n=4-7$ independent experiments). None of the $\mathrm{G}_{2} / \mathrm{M}$ values were significantly different from the control $\mathrm{G}_{2} / \mathrm{M}$ value (One-way ANOVA, Dunnett's multiple comparison test).

\begin{tabular}{ccccc}
\hline Concentration MYZ (nM) & $\mathbf{G}_{\mathbf{1}} \mathbf{( \% )}$ & $\mathbf{S} \mathbf{( \% )}$ & $\mathbf{G}_{\mathbf{2}} / \mathbf{M} \mathbf{( \% )}$ & $\boldsymbol{n}$ \\
\hline 0 & $70.4 \pm 2.2$ & $15.5 \pm 0.6$ & $13.6 \pm 2.4$ & 7 \\
0.1 & $68.8 \pm 3.8$ & $17.4 \pm 2.1$ & $14.2 \pm 2.8$ & 4 \\
1 & $70.4 \pm 3.6$ & $15.9 \pm 1.4$ & $14.0 \pm 2.6$ & 4 \\
10 & $69.6 \pm 2.1$ & $15.5 \pm 1.2$ & $15.2 \pm 1.1$ & 5 \\
100 & $69.9 \pm 2.9$ & $15.4 \pm 1.8$ & $15.0 \pm 1.3$ & 5 \\
\hline
\end{tabular}

Figure 6. Lack of effect of MYZ on cell cycle of HeLa cells after 24 and $48 \mathrm{~h}$ exposure. (A) Representative cell cycle distribution after $24 \mathrm{~h}$ treatment with MYZ at concentrations of $0 \mathrm{nM}$ (Control; gray shaded area), $100 \mathrm{nM}$ (gray line), and $20 \mu \mathrm{M}$ (black line); (B) Summary table of cell cycle analysis of HeLa cells treated with varying concentrations of MYZ at $24 \mathrm{~h}$ and $48 \mathrm{~h}$. The average \% for two independent experiments is presented for MYZ concentrations of $0-100 \mathrm{nM}$. The 5 and $20 \mu \mathrm{M}$ concentrations are from a single determination.

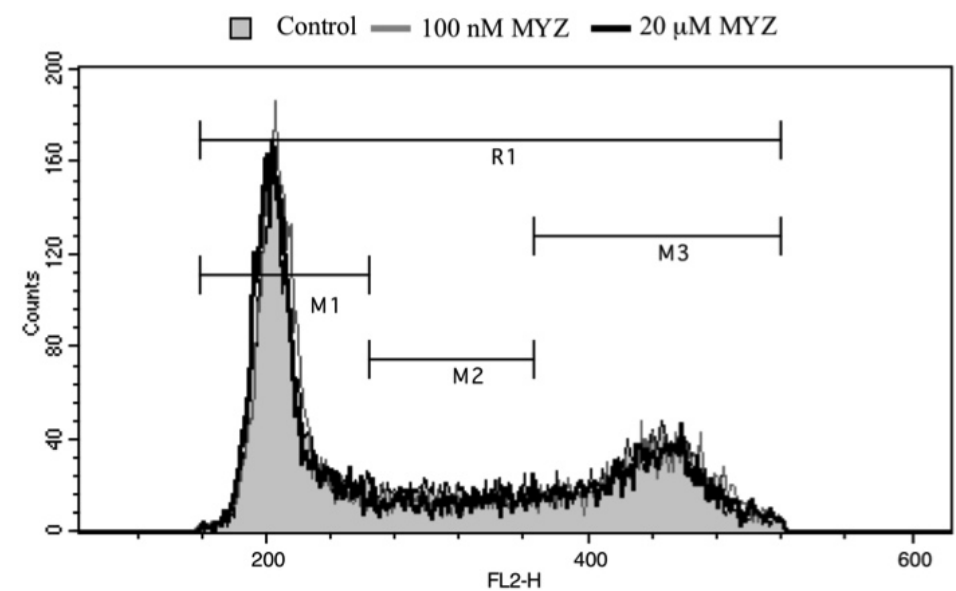

(A)

\begin{tabular}{|c|c|c|c|c|c|c|}
\hline \multirow{2}{*}{$\begin{array}{c}\text { Myz } \\
\text { Conc. }\end{array}$} & \multicolumn{3}{|c|}{ Percentage of Cells in Cell Cycle } & \multicolumn{3}{c|}{ Percentage of Cells in Cell Cycle } \\
$(\mathrm{nM})$ & $\mathrm{G}_{1}$ & $\mathrm{~S}$ & $\mathrm{G}_{2} / \mathrm{M}$ & $\mathrm{G}_{1}$ & $\mathrm{~S}$ & $\mathrm{G}_{2} / \mathrm{M}$ \\
\cline { 2 - 7 } & & 16.5 & 31.7 & 35.0 & 20.6 & 44.9 \\
\hline 0 & 50.6 & & & & & \\
\hline 1 & 55.9 & 12.3 & 32.3 & 46.5 & 15.0 & 38.9 \\
\hline 10 & 55.2 & 12.4 & 32.8 & 43.3 & 16.7 & 40.5 \\
\hline 100 & 54.9 & 12.0 & 33.5 & 43.0 & 15.0 & 42.4 \\
\hline 5,000 & 55.4 & 13.4 & 31.6 & 50.5 & 13.5 & 36.4 \\
\hline 20,000 & 55.5 & 13.6 & 31.2 & 43.5 & 15.9 & 40.9 \\
\hline
\end{tabular}

(B) 


\subsection{Effects of MYZ on ROS}

DCF (2,7-dichlorofluorescein) [17] was used to determine whether MYZ affected the production of reactive oxygen species (ROS) (Figure 7). After $24 \mathrm{~h}$ treatment with MYZ, decreased ROS levels were seen in both HeLa and P815 cells (Figure 7A,D) compared with untreated control cells, but by $48 \mathrm{~h}$, the DCF response had returned to control levels (Figure 7B,E). With HeLa ${ }^{0}$ at $48 \mathrm{~h}$ (Figure 7C) and $\mathrm{P} 815 \rho^{0}$ at $24 \mathrm{~h}$ (Figure 7F), some lesser shifts in DCF fluorescence were also observed. Dichloroacetate (DCA) was chosen as a positive control for increasing ROS in the cells; however, it proved to be too toxic to the cells at the two concentrations tested $(20 \mu \mathrm{M}$ and $2 \mu \mathrm{M})$.

Figure 7. Effects of MYZ on reactive oxygen species (ROS) as determined by dichlorofluorescein (DCF) fluorescence. Representative histograms of fluorescence intensity of DCF, a marker of ROS production, are presented for $\mathrm{HeLa}(\mathbf{A}, \mathbf{B})$ and P815 (D, E) cells $24 \mathrm{~h}$ and $48 \mathrm{~h}$ after addition of MYZ. Paclitaxel, a microtubule-stabilizing agent, was used as a negative control and dichloroacetate (DCA) as a positive control. DCF in HeLa $\rho^{0}$ at $48 \mathrm{~h}(\mathbf{C})$ and $\mathrm{P} 815 \rho^{0}$ at $24 \mathrm{~h}(\mathbf{F})$ are also presented. The geometric means of the fluorescence are presented in Table S1 of the Supplementary Data.
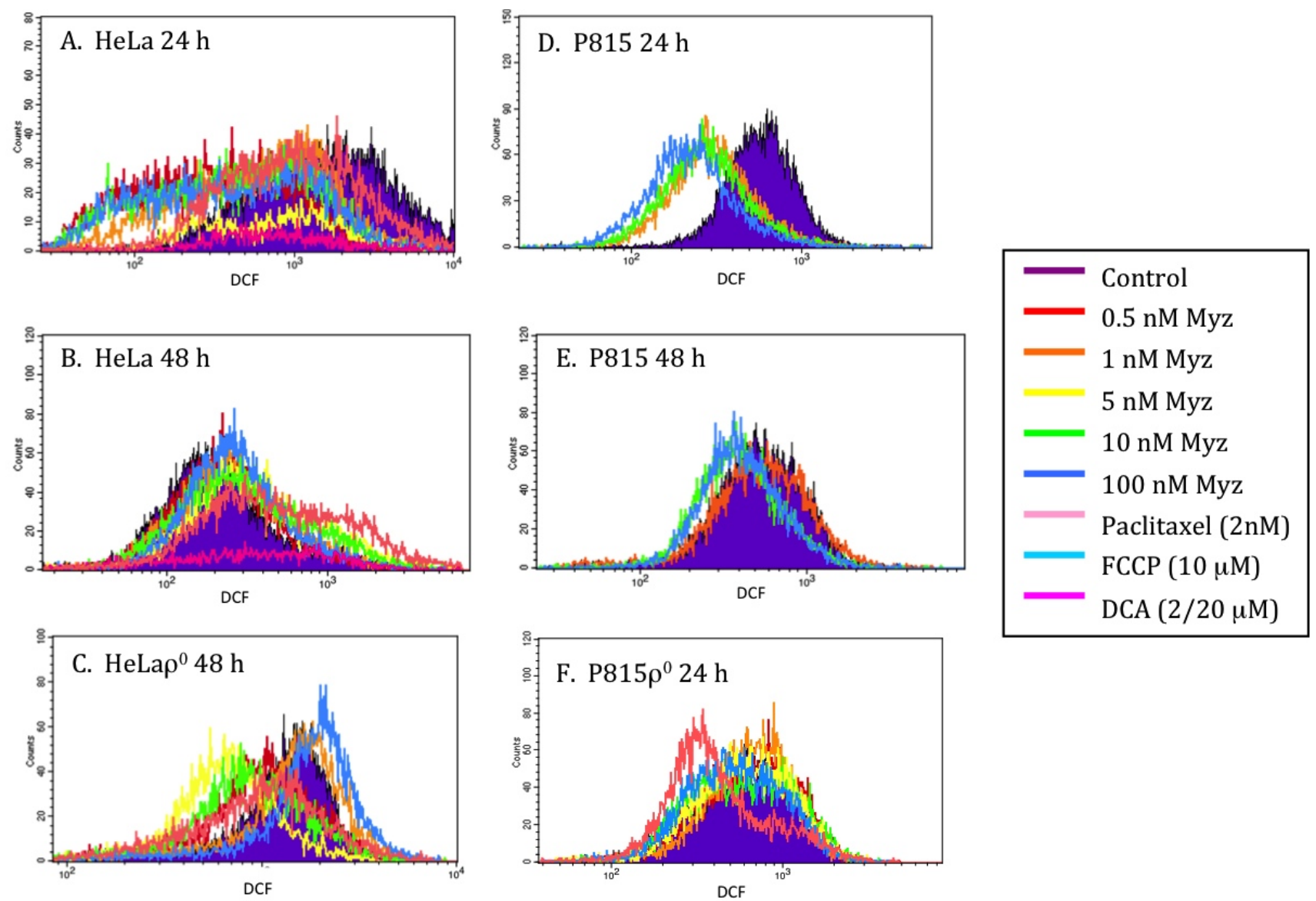

\subsection{MYZ Activity Range in Different Cell Lines and Dependence on Mitochondrial Function}

The mode of action of MYZ remained elusive until recently when Morgan et al. reported it to be a MET complex I inhibitor as well as an HIF-1 inhibitor [5,6]. These authors reported a large range in 
sensitivity of different cell lines to growth inhibition by MYZ, with the T47D breast cancer cell line being the most sensitive and another breast cancer cell line MDA-MB-231 being the least sensitive. McLaughlin [11] has also reported highly selective activity of acetogenins, potent complex I inhibitors, in different cell lines. When screened against the NCI 60 cell line panel, MYZ showed potent activity against the small and non-small lung cancer cell lines DMS114 (13 nM IC 50 ) and NCI-H23 $\left(250 \mathrm{nM} \mathrm{IC}_{50}\right)$; however, there was a broad range of activity in other cell lines from $0.1-100 \mu \mathrm{M}$ [4]. In HCT-116 colon cancer cells, MYZ had an $\mathrm{IC}_{50}$ of $3.8 \mathrm{nM}$ [18]. In our study, MYZ also showed a broad range of activity in different cancer cell lines. In another NCI study of MET complex 1 inhibitors [10], leukemic cell lines such as K562 were particularly sensitive, yet in our study, although splenic T cells were very sensitive, the leukemic cell lines HL-60 and Jurkat showed a high level of resistance to MYZ.

The nanomolar response in sensitive cells suggests a direct link between NADH flux and MET, a principal site of NADH oxidation in respiring cells. To investigate this link, a panel of $\rho^{0}$ cells was used. These cells lack mitochondrial DNA, and therefore have defective electron transport function at complexes I, III, and IV as well as having a non-functional cytochrome oxidase (complex V, [15]). Relative to MYZ-sensitive parental cells $\left(0.36-14 \mathrm{nM} \mathrm{IC}_{50}\right.$ range), $\rho^{0}$ cells for these same cell lines had low sensitivity to MYZ in the MTT assay with $\mathrm{IC}_{50}$ values in the range of 26-78 $\mu \mathrm{M}$. This amounts to a 2500-217,000-fold difference in MTT sensitivity between parental and $\rho^{0}$ cells. With HL-60 cells, on the other hand, the $\mathrm{IC}_{50}$ values were similar between the parental $(12 \mu \mathrm{M})$ and HL-60 $\rho^{0}(26 \mu \mathrm{M})$ cells. Thus, having functional MET made little difference to the effect of MYZ in this cell line. It was therefore concluded that MET was not necessary for the micromolar MYZ sensitivity seen in those cells.

In a preliminary test with rotenone (Figure S3 of Supplementary Data), MYZ-insensitive HL-60 cells gave $\mathrm{IC}_{50}$ values of $0.41 \mu \mathrm{M}$ for rotenone in wild type cells and $0.39 \mu \mathrm{M}$ in HL-60 $\rho^{0}$ cells. Thus, the independence of mitochondrial function was similar for both complex I inhibitor drugs. It is possible that resistant cell lines that normally use oxidative phosphorylation to generate ATP, such as HL-60, are able to shift their metabolism to aerobic glycolysis in the presence of a complex I inhibitor like MYZ or rotenone. A shift to aerobic glycolysis, commonly associated with cancer cells, is referred to as the Warburg effect. In a study by Xu et al. [19], a mitochondrial-deficient clone of HL-60 cells (HL-60/C6F) showed enhanced inhibition of cellular ATP levels in the presence of the glycolytic inhibitor 3-bromopyruvate at concentrations of 50-100 $\mu \mathrm{M}$, indicating that when mitochondrial function is impaired, the cells can alter their metabolism toward aerobic glycolysis. At a higher concentration of $300 \mu \mathrm{M}$ 3-bromopyruvate, however, both HL-60 and HL-60/C6F cells were completely depleted of ATP and underwent apoptosis.

Our findings with mitochondrial DNA-free cells are novel and suggest that the nanomolar effects of MYZ require MET function, but that MET function is not sufficient for these effects, since the insensitive cell lines were unaffected at nanomolar concentrations of MYZ, yet have normal mitochondrial function. Thus, some other factor or factors not present in insensitive cells appears to be required for the nanomolar effects of MYZ on MET. The nature of these MYZ-priming events and the extent to which they are involved with other complex I inhibitors is at present unknown. 


\subsection{MYZ Action on Metabolism, Cell Cycle, and Cell Viability}

Although MTT dye reduction assays are often referred to as cell proliferation assays, the assay primarily measures cytosolic $\mathrm{NAD}(\mathrm{P}) \mathrm{H}$ oxidoreductases [20,21] and therefore is more correctly a measure of cellular metabolic activity. Using this assay, we showed that MYZ had no effect on MTT responses of sensitive cells until at least $12 \mathrm{~h}$ exposure, with an apparent threshold effect at about $0.1 \mathrm{nM}$ MYZ in P815 cells. This contrasts with uncouplers such as FCCP that enhance MET and oxygen consumption within seconds. MET complex inhibitors, like rotenone and myxothiazol, azide and cyanide, also act within minutes to prevent NADH oxidation [22]. Hence, MYZ appears to be an atypical MET complex I inhibitor in its kinetics of action. The reasons for the delay in MYZ action could be due to a slow uptake into the cell, its likely membrane localization, or the need to generate an active metabolite before it can work on its target. In the study by Morgan et al. [6], using both intact and digitonin-permeabilized cells, MYZ, like rotenone, caused an immediate decrease in oxygen consumption by the cells. Just how this metabolic decrease from inhibition of complex I relates to actual cell growth inhibition, as measured in this study, is not known. In human CEM leukemic cells, McLaughlin [11] reported a 2 or 3 day lag period before significant depletion (up to $76 \%$ depletion) of ribonucleotide triphosphates occurred following addition of the acetogenin bullatacin.

No cell cycle block was observed in the sensitive HeLa cells after 24 or $48 \mathrm{~h}$ exposure, even at MYZ concentrations as high as $20 \mu \mathrm{M}$. This effect was not specific to HeLa cells since the nonsensitive HL-60 cells also failed to show the $\mathrm{G}_{2} / \mathrm{M}$ arrest seen with rotenone. These results are consistent with a generalized metabolic effect of MYZ in sensitive cells rather than a specific effect on different phases of the cell cycle. The results are opposite to that of the complex I inhibitor rotenone, which arrests cells in $\mathrm{G}_{2} / \mathrm{M}$ of the cell cycle [23,24].

In MYZ sensitive cells, the cells remained viable at concentrations of MYZ that extensively reduced metabolism. At higher micromolar concentrations, the MTT response correlated with loss of cell viability in both insensitive cells and in sensitive cells that have a biphasic response to the compound. This introduced the possibility that a second mode of action was involved at these higher concentrations in both types of cells. The second target may only be affected at high concentrations of MYZ because of a low sensitivity binding site, or alternatively, because MYZ is being metabolized to another bioactive compound that reaches its threshold concentration for the second target only at high concentrations. It seems unlikely that increases in ROS levels are involved in the cytotoxicity, since the DCF signal was decreased in HeLa and P815 cells after $24 \mathrm{~h}$ treatment with MYZ. It is surprising that MYZ reduced ROS levels in these two cell lines, given that complex I inhibitors like rotenone generally increase $\mathrm{O}_{2}{ }^{--}$, the predominant ROS in cells [10].

\subsection{Possible Mechanisms of MYZ Action}

\subsubsection{Lack of Correlation to NQO1 Reductase}

To understand the huge difference between $\mathrm{IC}_{50}$ values for $\mathrm{MYZ}$ between sensitive and insensitive cells, other differences between the cell lines were considered. For example, NAD(P)H:quinone oxidoreductase 1 (NQO1) levels vary substantially between different cell lines. NQO1 is an oxidoreductase that is involved in detoxifying quinones and also plays a role in the cellular response to 
oxidative stress $[25,26]$. There was no correlation, however in the different cell lines between NQO1 levels and sensitivity to MYZ. Thus, HL-60, an insensitive cell line, and P815 and B16, two sensitive cell lines, all have very low NQO1 levels; whereas, HeLa and MDCK, two other sensitive cell lines, have high levels of NQO1 ([27,28], and unpublished results).

\subsubsection{Differences between MYZ and Rotenone}

MYZ and rotenone are both MET complex I inhibitors, yet their activity profiles vary considerably. (i) There is a clear lack of $\mathrm{G}_{2} / \mathrm{M}$ arrest with $M Y Z$, despite a reported $\mathrm{G}_{2} / \mathrm{M}$ arrest by rotenone $[23,24]$. The explanation for this is that rotenone, in addition to its complex 1 inhibitory effect, also binds tubulin and inhibits its polymerization. This secondary, direct effect on tubulin and subsequent mitotic block by rotenone has been well established [29]. The $\mathrm{IC}_{50}$ for rotenone in inhibiting proliferation in HeLa cells was $0.2 \pm 0.1 \mu \mathrm{M}$, a concentration that also effectively depolymerized spindle microtubules and blocked mitosis [29]. (ii) ROS is decreased by MYZ compared with rotenone which increases ROS. (iii) in contrast to rotenone, MYZ has a long, $12 \mathrm{~h}$ lag period before metabolism is inhibited in the MTT assay. No such lag is seen in the inhibition by MYZ of oxygen consumption in non-permeabilized T47D cells [6]. MYZ is a small lipophilic molecule that should rapidly partition in membranes. Its movement to intracellular membrane systems, including mitochondrial membranes, may be slow compared with rotenone, resulting in delayed activation.

\subsubsection{Dual Target Mechanism and Future Directions}

The presence of both sensitive and insensitive cell lines and biphasic effects in some sensitive cells can be explained by a two-target mechanism for MYZ. At low nanomolar concentrations, the drug or metabolite may interact with a metabolic target, either directly or indirectly affecting complex I, hence the loss of the sensitivity to MYZ in $\rho^{0}$ cells. When higher concentrations are reached, a second target may be affected that causes cell death. Thus, the first target appears to be metabolic, since interaction at these concentrations does not kill the cells but has a cytostatic effect. This high sensitivity target is dependent on mitochondrial function since $\rho^{0}$ cells are not susceptible to low nanomolar MYZ concentrations. Although these data support complex I being the primary target in these cells, they do not explain the insensitivity of some cells with intact mitochondria and functional MET, such as HL-60, LN18, and Jurkat [30]. It is possible that these MYZ-insensitive cells are better able to alter their metabolism to aerobic glycolysis to overcome the action of a MET complex I inhibitor. The second, low sensitivity, micromolar target is not affected by loss of MET, as can be seen by similar MTT responses by HL-60 and HL- $60 \rho^{0}$ cells to MYZ (and to rotenone, Figure S3 of Supplementary Data). Inhibition via this second target has cytotoxic effects on cells (Figure 4), indicating a distinct non-mitochondrial mechanism of action.

\section{Experimental Section}

\subsection{MYZ Extraction and Purification}

Methanolic extracts of the marine sponge Cacospongia mycofijiensis, collected from 'Eua, Tonga were fractionated to generate MYZ in greater than $95 \%$ purity. All spectroscopic data, including 
${ }^{1} \mathrm{H}$ and ${ }^{13} \mathrm{C}$ NMR (Figure S1 of Supplementary Data), optical rotation and high-resolution mass spectrometry were in accordance with previously reported accounts of MYZ [1,3]. The NMR spectra $\left(\mathrm{CDCl}_{3}, 600 \mathrm{MHz}\right)$ were obtained using a Varian DirectDrive spectrometer equipped with a triple resonance $\mathrm{HCN}$ cryogenic probe. High-resolution positive-ion mass spectra were recorded on a Waters Q-TOF PremierTM Tandem Mass spectrometer. Optical rotations were performed using a Rudolph Autopol II polarimeter. Normal-phase column chromatography was carried out with silica gel. Reversed-phase column chromatography was achieved using Supelco Diaion HP20 poly(styrene-divinylbenzene) (PSDVB) chromatographic resin. HPLC was performed using a Rainin Dynamax SD-200 solvent delivery system, with UV detection using a Varian ProStar 335 photodiode array detector. Solvents used for flash normal- and reversed-phase column chromatography were of HPLC or analytical grade quality. All other solvents were purified by glass distillation. Solvent mixtures are reported as \% (v/v) unless otherwise stated. Cacospongia mycofijiensis sponge specimens were stored at $-20{ }^{\circ} \mathrm{C}$ until required for extraction. Frozen sponge $(21.0 \mathrm{~g})$ was extracted in $\mathrm{MeOH}$ $(2 \times 100 \mathrm{~mL})$ and loaded onto PSDVB. The loaded extracts were eluted with: (i) $30 \% \mathrm{Me}_{2} \mathrm{CO} / \mathrm{H}_{2} \mathrm{O}$, (ii) $75 \% \mathrm{Me}_{2} \mathrm{CO} / \mathrm{H}_{2} \mathrm{O}$ and (iii) $\mathrm{Me}_{2} \mathrm{CO}$. A portion of the $75 \% \mathrm{Me}_{2} \mathrm{CO} / \mathrm{H}_{2} \mathrm{O}$ fraction was fractionated further on PSDVB (30-100\% $\left.\mathrm{Me}_{2} \mathrm{CO} / \mathrm{H}_{2} \mathrm{O}\right)$. The $60-70 \% \mathrm{Me}_{2} \mathrm{CO} / \mathrm{H}_{2} \mathrm{O}$ fractions were further purified using silica gel $\left(\mathrm{CH}_{2} \mathrm{Cl}_{2}-\mathrm{EtOAc}\right)$. The $10-20 \% \mathrm{EtOAc} / \mathrm{CH}_{2} \mathrm{Cl}_{2}$ fractions were finally purified using HPLC (DIOL, $5 \mu \mathrm{m}, 4.6 \times 250 \mathrm{~mm}, 10 \% \mathrm{IPA} / n$-hexane) to yield mycothiazole $\left(5.7 \mathrm{mg}, t_{R}=5.5 \mathrm{~min}\right)$ as a colorless oil with the following properties: $[\alpha]_{\mathrm{D}}{ }^{20}-19.3^{\circ}\left(c 0.93, \mathrm{CHCl}_{3}\right)$; HRESIMS $[\mathrm{M}+\mathrm{H}]^{+}$, observed $m / z$ 405.2215, calculated $m / z 405.2212$ for $\mathrm{C}_{22} \mathrm{H}_{33} \mathrm{~N}_{2} \mathrm{O}_{3} \mathrm{~S}, \Delta=+0.7 \mathrm{ppm}$.

\subsection{Cell Culture}

Cell lines used in this study included murine splenic T-cells, adherent cell lines of human (HeLa cervical carcinoma, HeLa S3 semi-adherent clone, 143B osteosarcoma, LN18 glioblastoma), mouse (4T1 breast carcinoma, B16 melanoma), and dog origin (MDCK kidney epithelial), and non-adherent cell lines of human (HL-60 promyelocytic leukemia, Jurkat T-cell lymphoma) and mouse origin (P815 mastocytoma, RAW264.7 monocyte/macrophage). Cell lines were obtained from the following sources: HeLa (Professor Anthony Braithwaite, University of Otago), HeLa S3 (Dr. Alfons Lawen, University of Melbourne), 143B and 143B $\rho^{0}$ (Dr. Mike Murphy, University of Otago), P815 (Dr. John Marbrook, University of Auckland), HL-60 (Dr. Graeme Findlay, University of Auckland), Jurkat (Dr. Thomas Bäckström, Malaghan Institute, Wellington), LN18, 4T1, B16, MDCK, and RAW264.7 (ATCC, Manassas, VA). The parent lines are all phenotypically stable and exhibit properties characteristic of their cell or tissue of origin. HL-60 is regularly tested in our laboratory for respiratory burst activity and differentiation into neutrophils (retinoic acid) or monocytes (PMA or vitamin $\mathrm{D}_{3}$ ). Four of the five $\rho^{0}$ cell lines lacking mitochondrial DNA (HL-60 $\rho^{0}$, HeLa $\rho^{0}, \mathrm{P} 815 \rho^{0}$, and B16 $\rho^{0}$ ) used in this study, with the exception of $143 \mathrm{~B} \rho^{0}$, were generated in our laboratory by prolonged culture of the parental cell lines in the presence of ethidium bromide, followed by culture in its absence [14]. These phenotypically stable cell lines were auxotrophic for uridine and pyruvate. All $\rho^{0}$ cells were tested at regular intervals for loss of MET function by FCCP resistance of WST-1 reduction, and by PCR for absence of mitochondrially-encoded cytochrome $b$. 
The standard culture medium consisted of RPMI-1640 medium supplemented with $5-10 \%$ fetal calf serum, $2 \mathrm{mM}$ glutamate, $25 \mu \mathrm{g} / \mathrm{mL}$ penicillin, $25 \mu \mathrm{g} / \mathrm{mL}$ streptomycin, $50 \mu \mathrm{g} / \mathrm{mL}$ uridine, and $1 \mathrm{mM}$ pyruvate. Murine B16 cells, however, were cultured in complete medium (cIMDM) containing Iscove's modified Dulbecco's medium (IMDM), $2 \mathrm{mM}$ Glutamax ${ }^{\circledR}, 10 \%$ fetal calf serum, $100 \mathrm{U} / \mathrm{mL}$ penicillin, $100 \mu \mathrm{g} / \mathrm{mL}$ streptomycin with $50 \mu \mathrm{g} / \mathrm{mL}$ uridine and $1 \mathrm{mM}$ pyruvate. RAW264.7 cells and CD4/CD8 $\mathrm{T}$ cells isolated from the mouse spleen were cultured in a DMEM-based complete $\mathrm{T}$ cell medium containing 10\% FCS and other supplements as previously described [31]. All cells were grown at $37{ }^{\circ} \mathrm{C}$ in an atmosphere of $5 \% \mathrm{CO}_{2}$ in air and high humidity. Adherent cell lines were passaged using TrypLETM Express (Invitrogen) to detach the cells, washed with medium, and then passaged into fresh medium.

\subsection{Cell Metabolism Assay}

An MTT cell proliferation assay [20,21] was used to measure cell metabolism. Cells reduce the yellow 3-(4,5-dimethylthiazol-2-yl)-2,5-diphenoyltetrazolium bromide (MTT) dye to blue formazan crystals in a manner dependent on intracellular reduced pyridine nucleotides, and therefore the assay is a measure of cell metabolism. Cells were seeded at a density of $1 \times 10^{4}$ cells/well in a 96-well plate and treated with varying concentrations of MYZ for different lengths of time. MTT solution $(20 \mu \mathrm{L}$ of $5 \mathrm{mg} / \mathrm{mL}$ in PBS) was added to each well, and after $2 \mathrm{~h}$ incubation, $100 \mu \mathrm{L}$ of solubilizer (10\% SDS, $45 \% \mathrm{~N}, \mathrm{~N}$-dimethylformamide) was added to lyse the cells and dissolve the blue crystals. The absorbance was measured at $570 \mathrm{~nm}$ using a multi-well plate reader. Absorbances were then used to generate concentration-response curves and to calculate $\mathrm{IC}_{50}$ values (the concentration at which MTT reduction is $50 \%$ of a non-treated control) using SigmaPlot software.

\section{4. ${ }^{3}$ H-Thymidine Uptake}

Cells were seeded in 96-well plates at a density of $1 \times 10^{5}$ cells $/ \mathrm{mL}$ and treated with MYZ. For the last $8 \mathrm{~h}$ of culture, $1 \mu \mathrm{Ci}{ }^{3} \mathrm{H}$-thymidine was added to each well, and the plates were frozen to stop cell proliferation. After thawing, the cells in each well were transferred to filters using a cell harvester (Tomtec, Hamden, CT) and the radioactivity determined in a liquid scintillation counter (Wallac MicroBeta TriLux).

\subsection{CFSE Cell Proliferation Assay}

In primary cultures of splenic $\mathrm{T}$ cells, a carboxyfluorescein succinimidyl ester (CFSE) proliferation assay was used to determine the $\mathrm{IC}_{50}$ for growth inhibition, as previously described [31]. Briefly, splenocytes were isolated from female C57BL/6 mice and stained with $1 \mu \mathrm{M}$ CFSE. Cells were then treated with different concentrations of MYZ in the presence or absence of Con A $(3 \mu \mathrm{g} / \mathrm{mL}$; Sigma Chemical Co.) for $48 \mathrm{~h}$. The cells were then harvested and stained with fluorescently-labelled antibodies (anti-CD4-cychrome c and anti-CD8-PE; BD Biosciences) or isotype controls, according to the manufacturer's recommendations, and analyzed by flow cytometry using a FACScan (Becton Dickinson). A total of 10,000 events were collected for each assay, and the data were analyzed by CellQuest Pro software (Becton Dickinson). 


\subsection{Trypan Blue Assay for Cell Viability}

A trypan blue dye exclusion assay was used to determine cell viability. Cells $\left(1 \times 10^{5} / \mathrm{mL}\right)$ were cultured with varying concentrations of MYZ and then stained with trypan blue and counted in a hemocytometer.

\subsection{Cell Cycle Analysis}

Flow cytometric analysis of cell DNA content following staining with propidium iodide (PI) was used to assess progression through the cell cycle. Cells were seeded at $1 \times 10^{5}$ cells/well in 24 -well plates and incubated with MYZ for various times. The cells were detached with $50 \mu \mathrm{L}$ TrypLE ${ }^{\mathrm{TM}}$ Express, washed in PBS, and then incubated with $250 \mu \mathrm{L}$ of PI solution $(0.05 \mathrm{mg} / \mathrm{mL}$ PI, $0.1 \%$ sodium citrate, $0.1 \%$ Triton X-100 in PBS). Samples were scanned and analyzed on a FACScan flow cytometer with BD Cell Quest Pro software.

\subsection{Measurement of Cellular ROS}

Mitochondrial ROS was measured by flow cytometry using changes in fluorescence of dichlorofluorescein (DCF). Briefly, cells were prepared as for cell cycle analysis, then $230 \mu \mathrm{L}$ of $10 \mu \mathrm{M}$ DCF in PBS was added and left for $30 \mathrm{~min}$. PI (20 $\mu \mathrm{L}$ of $100 \mu \mathrm{g} / \mathrm{mL})$ was also added to allow gating on only live, PI-negative cells. The samples were then scanned on a FACScan flow cytometer with BD Cell Quest Pro software.

\section{Conclusions}

The main finding of this study was that MYZ requires mitochondrial function to exert its nanomolar effects, providing support for its action as a MET complex I inhibitor, but that some cell lines display a biphase response or are resistant to the action of the compound. Studies on isolated mitochondria and individual MET complex activities may better define the cellular mechanism of action of MYZ. It would be interesting to compare the effect of MYZ on mitochondrial oxygen consumption in sensitive and insensitive cell lines. This would clarify whether differences in sensitivity to the drug are due to drug uptake/efflux mechanisms or different targets. It would also be interesting to explore the secondary cytotoxic mechanism of action of MYZ that occurs in cells at high, micromolar concentrations.

\section{Acknowledgments}

Financial support for this work was provided in part by the Cancer Society of New Zealand, the Wellington Medical Research Foundation, and Victoria University of Wellington.

\section{References}

1. Crews, P.; Kakou, Y.; Quinoa, E. Mycothiazole, a polyketide heterocycle from a marine sponge. J. Am. Chem. Soc. 1988, 110, 4365-4368. 
2. Mahler, G.; Serra, G.; Dematteis, S.; Saldana, J.; Dominguez, L.; Manta, E. Synthesis and biological evaluation of simplified mycothiazole analogues. Bioorg. Med. Chem. Lett. 2006, 16, 1309-1311.

3. Sonnenschein, R.N.; Johnson, T.A.; Tenney, K.; Valeriote, F.A.; Crews, P. A reassignment of (-)-mycothiazole and the isolation of a related diol. J. Nat. Prod. 2006, 69, 145-147.

4. Developmental Therapeutics Program (DTP) web site. Available online: http://dtp.nci.nih.gov (accessed on 10 November 2011), NIH NSC number 647640.

5. Morgan, J.B.; Liu, Y.; Zhou, Y.D.; Nagle, D.G. Mycothiazole Potently Inhibits Hypoxia-inducible Factor-1 (HIF-1) Activation in Breast and Prostate Tumor Cells. In Proceedings of the 48th Annual Meeting of the American Society Pharmacognosy, Portland, ME, USA, 14-18 July 2007; Abstract P007M.

6. Morgan, J.B.; Mahdi, F.; Liu, Y.; Coothankandaswamy, V.; Jekabsons, M.B.; Johnson, T.A.; Sashidhara, K.V.; Crews, P.; Nagle, D.G.; Zhou, Y.D. The marine sponge metabolite mycothiazole: A novel prototype mitochondrial complex I inhibitor. Bioorg. Med. Chem. 2010, 18, 5988-5994.

7. Scatena, R.; Bottoni, P.; Botta, G.; Martorana, G.E.; Giardina, B. The role of mitochondria in pharmacotoxicology: A reevaluation of an old, newly emerging topic. Am. J. Physiol. Cell Physiol. 2007, 293, C12-C21.

8. Petrosillo, G.; di Venosa, N.; Ruggiero, F.M.; Pistolese, M.; D’Agostino, D.; Tiravanti, E.; Fiore, T.; Paradies, G. Mitochondrial dysfunction associated with cardiac ischemia/reperfusion can be attenuated by oxygen tension control. Role of oxygen-free radicals and cardiolipin. Biochim. Biophys. Acta 2005, 1710, 78-86.

9. Ralph, S.J.; Moreno-Sánchez, R.; Neuzil, J.; Rodríguez-Enríquez, S. Inhibitors of succinate: Quinone reductase/Complex II regulate production of mitochondrial reactive oxygen species and protect normal cells from ischemic damage but induce specific cancer cell death. Pharm. Res. 2011, 28, 2695-2730.

10. Glover, C.J.; Rabow, A.A.; Isgor, Y.G.; Shoemaker, R.H.; Covell, D.G. Data mining of NCI's anticancer screening database reveals mitochondrial Complex I inhibitors cytotoxic to leukemia cell lines. Biochem. Pharmacol. 2007, 73, 331-340.

11. McLaughlin, J.L. Paw paw and cancer: Annonaceous acetogenins from discovery to commercial products. J. Nat. Prod. 2008, 71, 1311-1321.

12. Ly, J.D.; Lawen, A. Transplasma membrane electron transport: Enzymes involved and biological function. Redox Rep. 2003, 8, 3-21.

13. Herst, P.; Tan, A.; Scarlett, D.; Berridge, M. Cell surface oxygen consumption by mitochondrial gene knockout cells. Biochim. Biophys. Acta 2004, 1656, 79-87.

14. King, M.; Attardi, G. Human cells lacking mtDNA: Repopulation with exogenous mitochondria by complementation. Science 1989, 246, 500-504.

15. Curbo, S.; Johansson, M.; Balzarini, J.; Lewis, L.; Karlsson, A. Acute cytotoxicity of arabinofuranosyl nucleoside analogs is not dependent on mitochondrial DNA. Exp. Cell Res. 2009, 315, 2539-2543. 
16. Field, J.J.; Singh, A.J.; Kanakkanthara, A.; Halafihi, T.; Northcote, P.T.; Miller, J.H. Microtubule-stabilizing activity of Zampanolide, a potent macrolide isolated from the Tongan marine sponge Cacospongia mycofijiensis. J. Med. Chem. 2009, 52, 7328-7332.

17. Eruslanov, E.; Kusmartsev, S. Identification of ROS using oxidized DCFDA and flow-cytometry. Meth. Mol. Biol. 2010, 594, 57-72.

18. Sashidhara, K.; White, K.; Crews, P.A. Selective account of effective paradigms and significant outcomes in the discovery of inspirational marine natural products. J. Nat. Prod. 2009, 72, 588-603.

19. Xu, R.H.; Pelicano, H.; Zhou, Y.; Carew, J.S.; Feng, L.; Bhalla, K.N.; Keating, M.J.; Huang, P. Inhibition of glycolysis in cancer cells: A novel strategy to overcome drug resistance associated with mitochondrial respiratory defect and hypoxia. Cancer Res. 2005, 65, 613-621.

20. Berridge, M.V.; Tan, A.S. Characterization of the cellular reduction of 3-(4,5-dimethyl thiazol-2-yl)-2,5-diphenyltetrazolium bromide (MTT): Subcellular localization, substrate dependence, and involvement of mitochondrial electron transport in MTT reduction. Arch. Biochem. Biophys. 1993, 303, 474-482.

21. Berridge, M.V.; Herst, P.M.; Tan, A.S. Tetrazolium dyes as tools in cell biology: New insights into their cellular reduction. Biotechnol. Annu. Rev. 2005, 11, 127-152.

22. Herst, P.; Peterson, T.; Jeram, P.; Baty, J.; Berridge, M. The antiproliferative effects of phenoxodiol are associated with inhibition of plasma membrane electron transport in tumour cell lines and primary immune cells. Biochem. Pharmacol. 2007, 74, 1587-1595.

23. Armstrong, J.S.; Hornung, B.; Lecane, P.; Jones, D.P.; Knox, S.J. Rotenone-induced $\mathrm{G}_{2} / \mathrm{M}$ cell cycle arrest and apoptosis in a human B lymphoma cell line PW. Biochem. Biophys. Res. Commun. 2001, 289, 973-978.

24. Gonçalves, A.P.; Máximo, V.; Lima, J.; Singh, K.K.; Soares, P.; Videira, A. Involvement of p53 in cell death following cell cycle arrest and mitotic catastrophe induced by rotenone. Biochim. Biophys. Acta 2011, 1813, 492-499.

25. Ross, D.; Kepa, J.; Winski, S.; Beall, H.; Anwar, A.; Siegel, D. NAD(P)H:Quinone oxidoreductase 1 (NQO1): Chemoprotection, bioactivation, gene regulation and genetic polymorphisms. Chem. Biol. Interact. 2000, 129, 77-97.

26. Ross, D. Quinone reductases multitasking in the metabolic world. Drug Metab. Rev. 2004, 36, 639-654.

27. Bello, R.; Gomez-Diaz, C.; Navas, P.; Villalba, J. NAD(P)H:Quinone oxidoreductase 1 expression, hydrogen peroxide levels, and growth phase in HeLa cells. Meth. Enzymol. 2004, 382, 234-244.

28. Tan, A.S.; Berridge, M.V. Evidence for NAD(P)H:Quinone oxidoreductase 1 (NQO1)-mediated quinone-dependent redox cycling via plasma membrane electron transport: A sensitive cellular assay for NQO1. Free Radic. Biol. Med. 2010, 48, 421-429.

29. Srivastava, P.; Panda, D. Rotenone inhibits mammalian cell proliferation by inhibiting microtubule assembly through tubulin binding. FEBS J. 2007, 274, 4788-4801.

30. Herst, P.; Berridge, M. Cell surface oxygen consumption: A major contributor to cellular oxygen consumption in glycolytic cell lines. Biochim. Biophys. Acta 2007, 1767, 170-177. 
31. Crume, K.P.; O’Sullivan, D.; Miller, J.H.; Northcote, P.T.; La Flamme, A.C. Delaying the onset of experimental autoimmune encephalomyelitis with the microtubule-stabilizing compounds, paclitaxel and peloruside A. J. Leuk. Biol. 2009, 86, 949-958.

Samples Availability: Available from the authors.

(C) 2012 by the authors; licensee MDPI, Basel, Switzerland. This article is an open access article distributed under the terms and conditions of the Creative Commons Attribution license (http://creativecommons.org/licenses/by/3.0/). 